\title{
The ten group Robson classification: a retrospective study to identify strategies to optimise caesarean section rates
}

\author{
Spandana S., Amarpali K. Shivanna*
}

Department of Obstetrics and Gynecology, DM Wayanad Institute of Medical Sciences, Meppadi, Kerala, India

Received: 24 October 2020

Accepted: 29 October 2020

\section{*Correspondence:}

Dr. Amarpali K. Shivanna,

E-mail: spandana.subbegowda@gmail.com

Copyright: (c) the author(s), publisher and licensee Medip Academy. This is an open-access article distributed under the terms of the Creative Commons Attribution Non-Commercial License, which permits unrestricted non-commercial use, distribution, and reproduction in any medium, provided the original work is properly cited.

\begin{abstract}
Background: Caesarean section rates have been increasing worldwide. For proper assessment, the ten group Robson classification is recommended by WHO for assessing CS rates. We are analyzing the caesarean section rates by classifying the caesarean sections using modified Robson's ten group classification. Objective of the current study was to estimate caesarean section rates in our hospital and to classify caesarean section using modified Robson's ten group classification system.

Methods: Current retrospective study was conducted in the department of obstetrics and gynaecology in a tertiary care hospital. The medical records were reviewed for a period of 12 months.

Results: Total number of deliveries during the study period was 315 . The total numbers of caesarean section were 159 and total vaginal deliveries were 156 . The caesarean section rate was $50.47 \%$. The main contributors to overall caesarean section rate were group $5(18.10 \%)$, group $2(13.96 \%)$ and group $1(5.71 \%)$. Women with one previous LSCS contributed majorly to the caesarean section rate. Higher CS rate was also seen in both group 2A (69.40\%) and group 4A (47.30\%) which had underwent induction of labour. More inclination towards trial of labour following CS for women with previous one LSCS can lower CS rates.

Conclusions: Modified Robson's classification is easily implementable and an effective tool for ongoing surveillance. The results can be compared between Institutions, states and countries. Having implemented the Robson classification and identified groups which contributed the most to the overall CS rate, interventions to reduce the same has to be our prime objective.
\end{abstract}

Keywords: Caesarean section, Robson classification, Induction of labour, Vaginal deliveries

\section{INTRODUCTION}

Caesarean section (CS) rates have been increasing worldwide and have caused concerns. ${ }^{1}$ Over the past 4.5 decades there has been dramatic increase in the caesarean section rates in both, developed as well as developing countries. This increase has been a subject of considerable debate. In 1985 WHO has proposed the ideal rate for caesarean section to be between $10-15 \% .^{2}$ The purpose of classification of woman into different groups is to identify woman where effective strategies like changing labour management protocols may help to optimize caesarean section rate. Dr. Michael Robson in
2011 proposed a need to adopt a standard classification system for easy comparison and improvement of obstetric care and introduced Robson classification to achieve this. For meaningful comparisons to be made world health organization recommends the use of the ten-group Robson classification as the global standard for assessing CS rates. ${ }^{2}$ We are analyzing the caesarean section rates by classifying the caesarean sections using modified Robson's ten group classification. It is important to evaluate whether the modified Robson's classification is feasible one to use in our setting and if so, it could be used for a common classification system for caesarean 
section. This constitutes the matter of the research being proposed.

\section{METHODS}

The aims and objectives of current study were to estimate caesarean section rates in our hospital and to classify caesarean sections by using modified Robson's ten group classification system.

Current study is a descriptive retrospective study which was conducted in the department of obstetrics and gynaecology in DM Wayanad institute of medical sciences, Wayanad, Kerala. The medical records were reviewed for a period of 12 months from January 2019 to December 2019.

\section{Inclusion criteria}

All pregnant women who had crossed the period of viability delivered during January 2019 to December 2019 were enrolled and classified according to Robson's classification system as given in (Figure 1).

\begin{tabular}{|c|c|}
\hline Group & Description \\
\hline 1 & Nullipara, singleton cephalic, $\geq 37$ weeks, spontaneous labour \\
\hline 2 & $\begin{array}{l}\text { Nullipara, singleton cephalic, } 237 \text { weeks } \\
\text { A: Induced } \\
\text { B: Caesarean section before labour }\end{array}$ \\
\hline 3 & Multipara, singleton cephalic, $\geq 37$ weeks, spontaneous labour \\
\hline 4 & $\begin{array}{l}\text { Multipara, singleton cephalic, } \geq 37 \text { weeks } \\
\text { A: Induced } \\
\text { B: Caesarean section before labour }\end{array}$ \\
\hline 5 & $\begin{array}{l}\text { Previous Caesarean section, singleton cephalic, } \geq 37 \text { weeks } \\
\text { A. Spontaneous labour } \\
\text { B. Induced labour } \\
\text { C. Caesarean section before labour }\end{array}$ \\
\hline 6 & $\begin{array}{l}\text { All nulliparous breeches } \\
\text { A. Spontaneous labour } \\
\text { B. Induced labour } \\
\text { C. Caesarean section before labour }\end{array}$ \\
\hline 7 & $\begin{array}{l}\text { All multiparous breeches (including previous Caesarean section) } \\
\text { A. Spontaneous labour } \\
\text { B. Induced labour } \\
\text { C. Caesarean section before labour }\end{array}$ \\
\hline 8 & $\begin{array}{l}\text { All multiple pregnancies } \\
\text { A. Spontaneous labour } \\
\text { B. Induced labour } \\
\text { C. Caesarean section before labour }\end{array}$ \\
\hline 9 & $\begin{array}{l}\text { All abnormal lies (including previous Caesarean section but excluding breech) } \\
\text { A. Spontaneous labour } \\
\text { B. Induced labour } \\
\text { C. Caesarean section before labour }\end{array}$ \\
\hline 10 & $\begin{array}{l}\text { All singleton cephalic, } \leq 36 \text { weeks (including previous Caesarean section) } \\
\text { A. Spontaneous labour } \\
\text { B. Induced labour } \\
\text { C. Caesarean section before labour }\end{array}$ \\
\hline
\end{tabular}

Figure 1: Robson's ten group classification system.

The following variables as per Robson's classification system were collected; details regarding parity, gestational age, mode of previous deliveries, onset of labour, lie, presentation, mode of delivery, indication for caesarean section.
Overall CS rate, relative size of each group and relative contribution of each group to the overall CS rate were calculated. After obtaining ethical clearance from the ethical committee of the institution, data was collected and entered in Microsoft excel sheet and was later analyzed using statistical SPSS 20 software, appropriate statistical tests were applied to analyze the data.

\section{RESULTS}

Total number of deliveries during the study period was 315. The total number of caesarean sections was 159 and total vaginal deliveries were 156 . The caesarean section rate was $50.47 \%$. Vaginal delivery rate was $49.52 \%$. Caesarean section rate in this study is $50.47 \%$ which is higher than the WHO standards. Distribution of deliveries across ten groups is shown in (Figure 2).

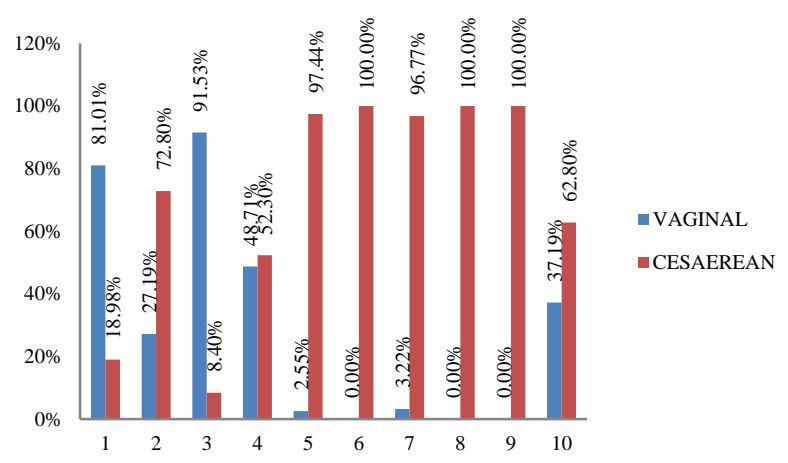

Figure 2: Distribution of deliveries across the ten groups.

The contribution of group 1 to overall caesarean section rate is $5.714 \%$. The contribution of group 5 to overall caesarean section rate is $18.10 \%$. This group is the major contributor to the caesarean section rate. CS rate in this group was $97.44 \%$. $99.32 \%$ of women had caesarean section before onset of labour. The contribution of group 3,4 and 6 to overall caesarean section rate is $0.63 \%$, $3.49 \%$ and $2.85 \%$ respectively. Contribution of each group of Robson's classification to overall caesarean section rates is shown in (Figure 3).

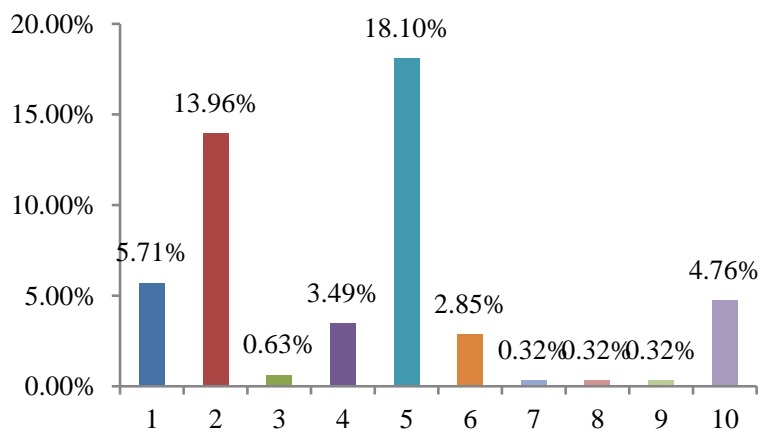

Figure 3: Contribution of each group of Robson's classification to overall caesarean section rates. 
Table 1: Caesarean section rate by ten group Robson classification.

\begin{tabular}{|c|c|c|c|}
\hline & $\begin{array}{l}\text { Relative size of groups } \\
\text { ( } \% \text { of total number of } \\
\text { births). }\end{array}$ & $\begin{array}{l}\text { CS rate in each } \\
\text { groups. }(\%)\end{array}$ & $\begin{array}{l}\text { Contribution made by each group } \\
\text { to overall CS rate. }(\%)\end{array}$ \\
\hline $\begin{array}{l}\text { Group } 1, \text { nulliparous, single, } \\
\text { cephalic, } \geq 37 \text { weeks, } \\
\text { spontaneous labour }\end{array}$ & 16.4 & 18.98 & 5.71 \\
\hline $\begin{array}{l}\text { Group 2, nulliparous, single } \\
\text { cephalic, } \geq 37 \text { weeks }\end{array}$ & 22.5 & 72.80 & \multirow{3}{*}{13.96} \\
\hline Induced & 14.7 & 69.4 & \\
\hline CS before labour. & 7.8 & 97.60 & \\
\hline $\begin{array}{l}\text { Group } 3 \text {, multiparous, single, } \\
\text { cephalic, } \geq 37 \text { weeks, } \\
\text { spontaneous labour }\end{array}$ & 21.1 & 8.40 & 0.63 \\
\hline $\begin{array}{l}\text { Group } 4 \text {, multiparous, single, } \\
\text { cephalic, } \geq 37 \text { weeks }\end{array}$ & 11.2 & 52.30 & \multirow{3}{*}{3.49} \\
\hline Induced & 6.9 & 47.3 & \\
\hline CS before labour & 4.3 & 80.7 & \\
\hline $\begin{array}{l}\text { Group 5, previous CS, } \\
\text { singleton, cephalic, } \geq 37 \text { weeks }\end{array}$ & 14.9 & 97.44 & \multirow{4}{*}{18.10} \\
\hline Spontaneous labour & 5.3 & 91.40 & \\
\hline Induced & 2.1 & 100 & \\
\hline CS before labour & 7.5 & 99.32 & \\
\hline $\begin{array}{l}\text { Group 6, All nulliparous } \\
\text { breeches }\end{array}$ & \multirow{4}{*}{1.2} & 100 & \multirow{4}{*}{2.85} \\
\hline Spontaneous labour & & 100 & \\
\hline Induced & & 0.00 & \\
\hline CS before labour & & 100 & \\
\hline $\begin{array}{l}\text { Group 7, all multiparous } \\
\text { breeches* }\end{array}$ & \multirow{4}{*}{1.9} & 96.77 & \multirow{4}{*}{0.32} \\
\hline Spontaneous labour & & 91.66 & \\
\hline Induced & & 0.00 & \\
\hline CS before labour & & 100 & \\
\hline $\begin{array}{l}\text { Group 8, all multiple } \\
\text { pregnancies* }\end{array}$ & \multirow{4}{*}{2.1} & 100 & \multirow{4}{*}{0.32} \\
\hline Spontaneous labour & & 0.00 & \\
\hline Induced & & 0.00 & \\
\hline CS before labour & & 100 & \\
\hline Group 9, all abnormal lies* & \multirow{4}{*}{0.9} & 100 & \multirow{4}{*}{0.32} \\
\hline Spontaneous labour & & 0.00 & \\
\hline Induced & & 0.00 & \\
\hline CS before labour & & 100 & \\
\hline $\begin{array}{l}\text { Group } 10, \text { all singleton cephalic, } \\
\leq 36 \text { weeks* }\end{array}$ & \multirow{4}{*}{7.8} & 62.80 & \multirow{4}{*}{4.76} \\
\hline Spontaneous labour & & 38.70 & \\
\hline Induced & & 64.78 & \\
\hline CS before labour & & 95.50 & \\
\hline Total & 100 & & 50.47 \\
\hline
\end{tabular}

*Groups 7-10 include women with previous CS.

The next major contributor to overall caesarean rate is by group 2 which is $13.96 \%$. This group includes nulliparous, singleton, cephalic induced or section done before labour. CS rate was $14.7 \%$ in induced group which 
was more than expected. Group 7, 8 and 9 contributed equally in CS rate, which was $0.317 \%$. The contribution of group 10 to overall caesarean section rate is $4.76 \%$. This group is important as it is often quoted by many tertiary referral units as to reason that their caesarean section rate is high. The size of the group is usually 4 to $5 \%$ of total and may indeed be higher up to $10 \%$ in some tertiary referral units. The rate of caesarean section in each group is shown in (Table 1).

\section{DISCUSSION}

WHO stated in 1985 that no region should exceed rates higher than $10-15 \%$ of caesarean sections. ${ }^{2}$ But the caesarean section rate in our study is $50.47 \%$ which is about thrice the expected. This classification helps us to identify groups which contributed the most to the overall CS rate. There by quality improvement activity could be implemented to modify the caesarean section rate in a particular group.

It is evident that, the caesarean section rate in group 2 and 4 is more than group 1 and 3 . There is a rising trend in the incidence of induction of labour. ${ }^{3}$ This implies that induction of labour was associated with increased caesarean section rates. Strategies to reduce this have to be implemented. Proper management of labour, indication for induction, methods used for induction and the criteria used for failed induction has to be defined stringently. Any reduction in caesarean section in this group would reduce CS rate not only in the present condition, but would also reduce number of women in group 5 in the future years. ${ }^{4}$

Group 3 and 1 had lower CS rate of $0.63 \%$ and $5.71 \%$ indicating multiparous women who were induced or who came in spontaneous labour had higher vaginal delivery rate. This also shows that nulliparous women in spontaneous labor also had lower caesarean section rates, indicating that we are dealing with a comparatively low risk population.

A major contributor to overall caesarean section rate is group 5. This is mainly because most women with previous one LSCS undergone an elective repeat caesarean section prior to labour. Even though vaginal delivery can be tried after one LSCS, women opting for the same has been declined over years due to fear of uterine rupture..$^{5,6}$ To reduce the caesarean section rate in group 5, a trial of labour (TOL) after caesarean section should be considered in every woman presenting for care, discussing the risk and benefits of VBAC while planning the birth and the primary sections has to be reduced. ${ }^{7}$

The contribution of group 6 and 7 to overall caesarean section rate is $2.85 \%$ and $0.317 \%$ respectively. Almost $100 \%$ of cases in group 6 and $96.77 \%$ in group 7 underwent caesarean section. This increase was seen post publication of term breech trial. ${ }^{8}$ ECV reduces a significant reduction of non cephalic births and caesarean section. It is recommended that all women with breech presentation should be offered an ECV, after explaining the risks and benefits. Trial of labour should be considered for breech after explaining the risks and benefits. The contribution of group 9 to overall caesarean section rate is $0.317 \%$. To decrease caesarean section in this group external version in to a breech or preferably a cephalic presentation should be attempted if the patient is at term or near term.

Robson group 1, 2 and 5 contributes to more than two third of overall caesarean section rate. In this study group 1,2 and 5 normally contributed to two thirds of overall caesarean section rate. Induction of labour was associated with higher $\mathrm{CS}$ rate in both groups $2 \mathrm{~A}$ and group 4A. In a study conducted by Samba et al at Ghana, caesarean section rate was $46.9 \%$ which is almost similar to our study. ${ }^{9}$ Groups 2, 4 and 5 contributed nearly half of the overall caesarean section rate which is similar in our study. According to Fatusic et al, caesarean section rate was $25.47 \%$ which was less than our study. Major contribution to caesarean section was by group 5,2 and group 1 and it is almost similar to our study in which group 2 and group 5 are the major contributions. ${ }^{10}$ This clearly demonstrates the significance of the Robson's criteria, where different institutions and countries would have to develop different strategies to address the caesarean section rates.

\section{Limitations}

In current study, sample size was small and study was conducted at a single center and hence the course of labour was possibly influenced by our hospital protocols and limited by the facilities available. Plan of delivery for a patient with uterine scar was not clear. It does not allow analysis of CS by demand and those for specific indication like placenta previa, more over it does not account for preexisting medical and surgical conditions or fetal distress.

\section{CONCLUSION}

Modified Robson's classification is easily implementable and an effective tool for ongoing surveillance. The results can be compared between Institutions, states and countries. All hospitals and hospital authorities can use the modified Robson's classification system as a part of a quality improvement initiative to monitor caesarean section rates. Having implemented the Robson classification and identified groups which contributed the most to the overall CS rate, interventions to reduce the same has to be our prime objective.

Funding: No funding sources Conflict of interest: None declared

Ethical approval: The study was approved by the Institutional Ethics Committee 


\section{REFERENCES}

1. Vogel JP, Betrán AP, Vindevoghel N, Souza JP, Torloni MR, Zhang J, et al. WHO multi-country survey on maternal and newborn health research network. Use of the Robson classification to assess caesarean section trends in 21 countries: a secondary analysis of two WHO multicountry surveys. Lancet Glob Health. 2015;3(5):e260-70.

2. WHO Statement on Caesarean Section Rates. Available at: https://www.who.int/reproductive health/publications/maternal_perinatal_health/csstatement/en/. Accessed on 24 July 2020.

3. Robson MS. Classification of caesarean sections. Fetal Mat Med Rev. 2001;12(1):23-39.

4. Le Ray C, Blondel B, Prunet C, Khireddine I, Deneux-Tharaux C, Goffinet F. Stabilising the caesarean rate: which target population?. BJOG. 2015;122(5):690-9.

5. Birth after Previous Caesarean Birth (Green Top Guideline 45). Available at: https://www.rcog. org.uk/en/guidelines-research-services/guidelines/ gtg45/. Accessed on 24 July 2020.

6. Vaginal birth after previous cesarean delivery, 2010. Available at: http://www.acog.org/Resources-AndPublications/Practice-. Accessed on 24 July 2020.
7. Gardner K, Henry A, Thou S, Davis G, Miller T. Improving VBAC rates: the combined impact of two management strategies. Aust N Z J Obstet Gynaecol. 2014;54(4):327-32.

8. Daviss BA, Johnson KC, Lalonde AB. Evolving evidence since the term breech trial: Canadian response, European dissent, and potential solutions. J Obstet Gynaecol Can. 2010;32(3):217-24.

9. Samba A, Mumani K. A review of caesarean sections using the ten group classification system (Robson's classification) in the Korle-Bu teaching hospital (KBTH), Accra, Ghana. Gynecol Obstet. 2006;6:385.

10. Fatusic J, Hudic I, Fatusic Z, Moralic AZ. Caesarean section rate analysis in university hospital Tuzlaaccording to Robson's classification. Med Arch. 2016;70(3):213-6.

Cite this article as: Spandana S, Shivanna AK. The ten group Robson classification: a retrospective study to identify strategies to optimise caesarean section rates. Int J Reprod Contracept Obstet Gynecol 2020;9:5082-6. 